Олександр Войтех,

Національний університет оборони України імені Івана Черняховського,

ORCID ID 0000-0003-1387-3188

\title{
ПІДГОТОВКА НАЦІОНАЛЬНОГО ПЕРСОНАЛУ ЗБРОЙНИХ СИЛ УКРАЇНИ ДО УЧАСТІ У МІЖНАРОДНИХ ОПЕРАЦІЯХ 3 ПІДТРИМАННЯ МИРУ І БЕЗПЕКИ ЯК ПЕДАГОГІЧНА ПРОБЛЕМА
}

Стаття присвячена дослідженню стану розробленості проблематики методичного забезпечення підготовки національного персоналу Збройних Сил Украӥни до участі у міжнародних операщіях з підтримання миру $і$ безпеки. Визначено фахові, психологопедагогічні та соиіокультурні особливості миротворчої діяльності військовослужбовців. На їх основі визначено специфічні принципи організації освітнього процесу підготовки військових фахівців до участі у міжнародних операціях з підтримання миру $i$ безпеки, а саме: інтеграції фахової, психолого-педагогічної, іншомовно-комунікативної підготовки; поєднання традиційних та інновачійних методів навчання; контекстного навчання; врахування соиіокультурного середовища виконання завдань. Обтрунтовано методичні рекомендації підготовки національного персоналу на основі моделі контекстного навчання.

Ключові слова: методичні рекомендації; модель контекстного навчання; специфічні принцичи навчання.

Постановка проблеми у загальному вигляді. Впродовж останніх років спостерігається низка радикальних перетворень у світовому безпековому секторі, що призводять до розгортання локальних збройних конфліктів. На фоні глобального напруження відбувся сплеск насильства і нестабільності на локально-регіональному рівні. До участі у розв'язанні більшості збройних конфліктів широко залучаються міжнародні організації, тимчасові коаліції держав, що діють під гаслом міжнародної діяльності 3 підтримання миру і безпеки.

На сьогодні, провідну роль у врегулюванні збройних конфліктів та формуванні глобального та регіонального безпекового середовища відіграють міжнародні організації (ООН, НАТО, ОБСЄ, СС), а також окремі держави або коаліції держав. Провідною організацією, що здійснює міжнародну діяльність 3 підтримання миру i безпеки, залишається Організація Об'єднаних Націй.

Україна бере активну участь у операціях з підтримання миру і безпеки, яка реалізується через співробітництво з ООН, ОБСЄ, НАТО та $з$ провідними державами світу [1].

Залучення до міжнародних операцій з підтримання миру і безпеки військовослужбовців Збройних Сил України, у якості національного персоналу, ставить завдання щодо їх належної підготовки. Реалізація миротворчих функцій передбачає готовність до виконання специфічних завдань, на сам перед пов'язаних із налагодженням комунікацій в іноземному соціокультурному середовищі, виконанням гуманітарних, поліцейських, 
миротворчих, адміністративних, технічних та інших невоєнних завдань, особливостями застосування зброї та технічних засобів, тощо.

Основу національної нормативно-правової бази щодо міжнародної діяльності з підтримання миру і безпеки складають: Конституція України, Закон України «Про оборону України», Закон України «Про Збройні Сили України», Закон України «Про участь України в міжнародних миротворчих операціях», Закон України «Про порядок направлення підрозділів Збройних Сил України до інших держав» Закон України «Про порядок допуску та умови перебування підрозділів Збройних сил інших держав на території України», Закон України «Про національну безпеку України», Воєнна доктрина України.

Питання підготовки національного персоналу у Збройних Силах України врегульовані низкою нормативно-правових актів [1; 2], також напрацьовані певні методичні рекомендації та узагальнення досвіду участі вітчизняних миротворчих сил [3; 4; 5; 6; 7].

Проте, розвиток форм збройної боротьби, застосування гібридних підходів у збройних конфліктах, еволюція озброєння та технічного забезпечення конфліктуючих сторін - обумовлюють потребу удосконалення методик підготовки військовослужбовців до участі в міжнародних операціях з підтримання миру і безпеки.

Педагогічна проблема підготовки національного персоналу полягає, на нашу думку, в імплементації сучасних педагогічних підходів та технологій у цей процес, що й зумовлює актуальність даного дослідження.

Метою статі $\epsilon$ обгрунтування методичних рекомендацій застосування сучасних педагогічних підходів та технологій у процес підготовки національного персоналу.

Аналіз наукових праць засвідчив, що питання підготовки миротворців не стало предметом широкого обговорення у наукових колах. Особливостям миротворчої діяльності та системи підготовки особового складу Збройних Сил України у своїх працях приділили увагу Л. Галуза, В. Кожевніков, Л. Маслак, О. Мельник, О. Плахотнік, О. Телічкін, В. Хацановський та ін.

Окремі аспекти миротворчої діяльності досліджували: В. Балабін розглядав міжнародну миротворчу діяльність як основу інтеграційних процесів у сфері безпеки [8], В. Стасюк - питання морально-психологічного забезпечення миротворчої діяльності [9], Д. Сохадзе - особливості професійно психологічного відбору миротворців [10], Ю. Захарчишина педагогічні умови підготовки офіцерів Збройних Сил України до соціокультурної діяльності в миротворчих місіях [11, 12].

Теоретичні та методичні засади військової освіти досліджували О. Барабанщиков, О. Безносюк, А. Вітченко, М. Нещадім, Н. Феденко, В. Ягупов та ін.

Однак, методика застосування сучасних педагогічних технологій у процесі підготовки національного персоналу не було предметом окремого дослідження. 


\section{Виклад основного матеріалу дослідження.}

Під національним персоналом ми розуміємо окремих військовослужбовці, працівників Збройних Сил України та інших державних органів і цивільних установ України, які направляються Україною для участі в міжнародних операціях з підтримання миру і безпеки і не входять до складу національного контингенту.

Слід зазначити, що до участі у складі національного персоналу залучається найкраще підготовлений, у фаховому відношенні, особовий склад 3 відповідним рівнем володіння іноземною мовою. Тому спеціальне навчання, спрямоване на досягнення готовності до виконання завдань у складі національного персоналу, має враховувати власне їх специфіку та будуватися на відповідних принципах.

Предметом методики підготовки миротворців $\epsilon$ процес викладання загальновійськових та військово-спеціальних дисциплін у військовому навчальному підрозділі, а саме його внутрішня (закони, закономірності і принципи) та зовнішня (зміст, методи та форми) складові, організація контролю й моніторингу її результативності.

Курси підготовки національного персоналу мають передбачати озброєння слухачів фаховими, психолого-педагогічними, комунікативними знаннями, які забезпечать ефективний перебіг комунікативного процесу в іноземному соціокультурному середовищі. Формування комунікативної компетентності як процесу цілеспрямованого та організованого оволодіння комунікативними вміннями побудоване на інтеграції відомостей військового фаху, соціальної психології, педагогіки та мовознавства.

Враховуючи особливості міжнародних операцій з підтримання миру $\mathrm{i}$ безпеки, освітній процес слід будувати на основі специфічних принципів, а саме:

інтеграції фахової, психолого-педагогічної, іншомовно-комунікативної підготовки;

поєднання традиційних та інноваційних методів навчання;

контекстного навчання;

врахування соціокультурного середовища виконання завдань.

Реалізація принципу інтеграції фахової, психолого-педагогічної, іншомовно-комунікативної підготовки має полягати через вивчення тем 3 культури спілкування з іноземцями, психології розв'язання конфліктних ситуацій, психології ведення службових нарад, віддання наказів i розпоряджень персоналу. При цьому, вивчення запропонованого матеріалу доцільно проводити на практичних заняттях за допомогою методів активного навчання.

Використовувати можливості контекстного навчання - методи активного навчання, орієнтованого на підготовку фахівців до участі в міжнародних операціях з підтримання миру і безпеки, яка реалізується за допомогою системного використання контексту конфлікту до врегулювання якого залучатиметься персонал, поступового насичення навчального процесу 
елементами сучасних міжнародних операцій з підтримання миру і безпеки. Контекстне навчання дозволяє реалізувати динамічну модель (Рис. 1) руху від навчальної (з використанням традиційних методів, наприклад лекцій, семінарів) через квазіпрофесійну (ігрові методи) та навчально-професійну (практика, стажування та ін.) до професійної миротворчої діяльності за допомогою, відповідно, семіотичної, імітаційної та соціальної навчальних моделей. Якщо у традиційних формах навчальної діяльності реалізуються головним чином процедури передачі й засвоєння слухачам знакової інформації (семіотична навчальна модель), то у квазіпрофесійній діяльності в аудиторних умовах відтворюється предметний та соціальний зміст засвоюваної діяльності (імітаційна навчальна модель), а у навчальнопрофесійній діяльності майбутні миротворці вже виконують професійні дії й завдання. Форми організації такої діяльності відтворюють на практиці форми реальної миротворчої діяльності.

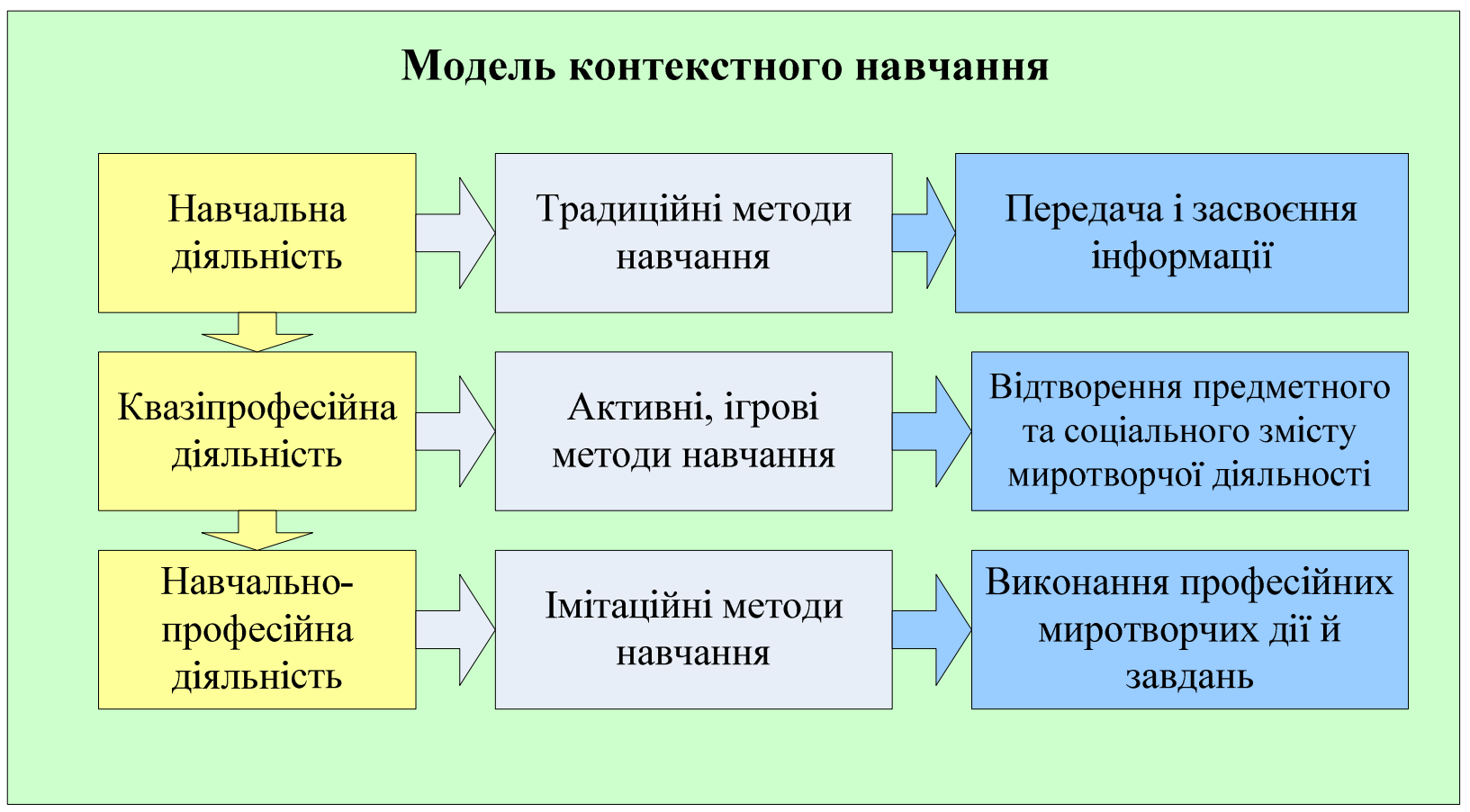

Рис. 1 - Модель контекстного навчання майбутніх миротворців

3 урахуванням змін у формах та методах збройної боротьби та протікання збройних конфліктів необхідно формувати базу квазіуправлінських завдань відповідно до специфіки завдань міжнародних операцій з підтримання миру і безпеки.

Важливого значення для підготовки національного персоналу набуває використання комунікативних та соціально-педагогічних тренінгів, рольових i ділових ігор як способів моделювання змісту майбутньої діяльності. Ефективним методом формування та розвитку необхідних здібностей, умінь і навичок $\epsilon$ соціально-педагогічний тренінг. Реалізація соціальнопедагогічного тренінгу допомагає майбутнім миротворцям набувати умінь встановлювати психологічний контакт, підтримувати i розвивати 
міжособистісні стосунки, адекватно сприймати, розуміти й оцінювати партнерів по спілкуванню, набувати $\mathrm{i}$ розвивати уміння та навички професійного психологічного впливу на населення конфліктуючої країни, сприяє розвитку психічної саморегуляції. Щодо комунікативного тренінгу, то він допомагає його учасникам усвідомити особисті позитивні й негативні риси; створити умови для ефективної співпраці, налагодження психологічного клімату; краще засвоїти певну інформацію.

Методичною настановою у підготовці військовослужбовців до миротворчої діяльності є також створення на заняттях відповідної соціальнопсихологічної атмосфери, а також спілкування і взаємодії викладачів та слухачів на основі принципів недирективності, особистісно орієнтованої взаємодії, суб'єкт-суб'єктності, що передбачає безумовне визнання особистості слухача, його розуміння, прийняття та оптимістичне прогнозування. У педагогічній взаємодії слухачів з науково-педагогічним складом важливе значення мають комунікативні здібності викладачів, їх уміння і навички спілкування. Від цього залежатиме створення у навчальних групах позитивного психологічного настрою, атмосфери взаємної вимогливості, конструктивності й товариськості.

Забезпечення реалізації зазначених настанов досягатиметься через постійне вдосконалення професійної та педагогічної майстерність науковопедагогічного складу, напрацювання методичних рекомендацій, врахування можливостей інформаційних технологій у навченому процесі.

Висновки. 3 огляду на інтеграцію України та міжнародних безпекових організацій, постійну участь військовослужбовців Збройних Сил України у операціях з підтримання миру і безпеки, зміну підходів до ведення збройної боротьби у збройних конфліктах сучасності - особливого значення набуває проблема підготовки військовослужбовців до діяльності у якості національного персоналу на основі науково-обгрунтованих педагогічних методик.

Процес підготовки національного персоналу має грунтуватися на специфічних принципах (інтеграції фахової, психолого-педагогічної, іншомовно-комунікативної підготовки; поєднання традиційних та інноваційних методів навчання; контекстного навчання; врахування соціокультурного середовища виконання завдань), що витікають із закономірностей міжнародної діяльності з підтримання миру і безпеки.

Методичною основою підготовки національного персоналу може стати модель контекстного навчання, яка реалізується за допомогою системного використання контексту конфлікту до врегулювання якого залучатиметься персонал, поступового насичення навчального процесу елементами міжнародної діяльності з підтримання миру і безпеки.

Перспективи подальшого дослідження вбачаємо в обгрунтуванні педагогічних умов впровадження методики підготовки національного персоналу на основі моделі контекстного навчання. 


\section{ЛІТЕРАТУРА}

1. Концепція організації міжнародного співробітництва у Збройних Силах України. Наказ Міністра оборони України від 28 червня 2001 року № 224 // www.mil.gov.ua/pravo /387/seach.cgi.

2. Про затвердження Інструкції про підготовку миротворчих контингентів i миротворчого персоналу 3С України для участі в ММО. Наказ Міністра оборони України від 25 жовтня 2004 року № 485 // www.mil.gov.ua/pravo /3412/seach.cgi.

3. Довідник з питань міжнародного військового співробітництва та участі України у міжнародних миротворчих операціях / Під загальною редакцією В.І. Банних. - К.: МОУ, 2001. - $210 \mathrm{c}$.

4. Міжнародне співробітництво та миротворча діяльність Збройних Сил України. Навчальний посібник. - К.: Вид. НАОУ, 2003. - 129 с.

5. Миротворча діяльність України: кооперація з НАТО та іншими структурами європейської безпеки. Наукове видання. - К: “Стилос”, 2002. - 345 с.

6. Підготовка та ведення миротворчих дій миротворчими контингентами та миротворчим персоналом Збройних Сил України: методичний посібник. - К.: ННДЦ ОТ і ВБ України, 2004. - 106 с.

7. Тематичний збірник: Збройні сили України у міжнародній миротворчій діяльності. Під загальною редакцією Шпури М.І. - К.: ННДЦ ОТ і ВБ України - 2004.

8. Сучасні міжнародні відносини і перспективи інтеграції України в євроатлантичну спільноту. Підручник. / Балабін В.В., Безносюк О.О., Заруба О.Г., та інші. За заг. ред. Балабіна В.В. - К.: ТОВ "Інфодрук", 2007. - 300 с.

9. Стасюк В.В. Досвід і проблеми морально-психологічного забезпечення міжнародного військового співробітництва / В.В. Стасюк // Збірник наукових праць НА ПВУ. - Хмельницький, 2003. - № 25. - Ч.2. - С.166-181.

10. СохадзеД.И. Профессиональній психологический отбор кандидатов для комплектования подразделений миротворческих сил: дис. канд. псих. наук: 19.00.06 Київ, 2004. - 190 с.

11. Захарчишина Ю. М. Педагогічні умови підготовки офіцерів Збройних Сил України до соціокультурної діяльності в миротворчих місіях: дис. канд. пед. наук: 13.00.04 - Житомир, 2011, - 348 с.

12. Захарчишина Ю. М. Підготовка офіцерів Збройних Сил України до соціокультурної діяльності в миротворчих місіях : метод. рекомендації / Ю. М. Захарчишина. - Житомир, Вид-во ЖДУ ім. І. Франка, 2011. - 119 с.

\section{REFERENCES}

1. Nakaz Ministra oborony Ukrainy "Kontseptsiia orhanizatsii mizhnarodnoho spivrobitnytstva u Zbroinykh Sylakh Ukrainy"[Concept of organization of international cooperation in the Armed Forces of Ukraine] as of June 28, 2001, n.o. 224, available at: http//www.mil.gov.ua/pravo /387/seach.cgi. (in Ukrainian).

2. Nakaz Ministra oborony Ukrainy "Pro zatverdzhennia Instruktsii pro pidhotovku myrotvorchykh kontynhentiv i myrotvorchoho personalu ZS Ukrainy dlia uchasti v MMO" [On Approval of the Instruction on the Training of Peacekeeping Contingents and Peacekeepers of the Armed Forces of Ukraine for Participation in International Peacekeeping Operations] as of October 25, 2004, n.o. 485, available at: http//www.mil.gov.ua/pravo /3412/seach.cgi. (in Ukrainian).

3. Bannykh, V. I. (2001). "Dovidnyk z pytan mizhnarodnoho viiskovoho spivrobitnytstva ta uchasti Ukrainy u mizhnarodnykh myrotvorchykh operatsiiakh" [Directory of international military cooperation and Ukraine's participation in international peacekeeping operations], - K.: MOU, p. 201-210 (in Ukrainian). 
4. Mizhnarodne spivrobitnytstvo ta myrotvorcha diialnist Zbroinykh Syl Ukrainy. [International cooperation and peacekeeping activities of the Armed Forces of Ukraine] Navchalnyi posibnyk. K.: Vyd. NAOU, p. 129, 2003 r. (in Ukrainian).

5. Myrotvorcha diialnist Ukrainy: kooperatsiia $\mathrm{z}$ NATO ta inshymy strukturamy yevropeiskoi bezpeky [Peacekeeping activity of Ukraine: cooperation with NATO and other structures of European security]. Naukove vydannia. K.: "Stylos", p. 345, 2002 r. (in Ukrainian).

6. Pidhotovka ta vedennia myrotvorchykh dii myrotvorchymy kontynhentamy ta myrotvorchym personalom Zbroinykh Syl Ukrainy [Preparation and conduct of peacekeeping operations by peacekeeping contingents and peacekeeping personnel of the Armed Forces of Ukraine Metodychnyi posibnyk. K.: NNDTs OT i VB Ukrainy, p. 106, 2004 r. (in Ukrainian).

7. Shpury, M. I. (2004). Zbroini syly Ukrainy u mizhnarodnii myrotvorchii diialnosti [Armed forces of Ukraine in international peacekeeping activity] Tematychnyi zbirnyk: - K.: NNDTs OT i VB Ukrainy (in Ukrainian).

8. Balabin, V. V., Beznosiuk, O. O., Zaruba, O. H., (2007). Suchasni mizhnarodni vidnosyny $\mathrm{i}$ perspektyvy intehratsii Ukrainy $\mathrm{v}$ yevroatlantychnu spilnotu [Contemporary international relations and prospects of Ukraine's integration into the Euro-Atlantic community] Pidruchnyk. K.: TOV "Infodruk"(in Ukrainian).

9. Stasiuk, V.V. (2003). Dosvid i problemy moralno-psykholohichnoho zabezpechennia mizhnarodnoho viiskovoho spivrobitnytstva [Experience and problems of moral and psychological support of international military cooperation], Khmelnytskyi, p.166-181 (in Ukrainian).

10. Sokhadze, D. Y. (2004). Professyonalnii psykholohycheskyi otbor kandydatov dlia komplektovanyia podrazdelenyi myrotvorcheskykh syl [Professional psychological selection of candidates for the recruitment of units of peacekeeping forces] Kyiv, p. 190 (in Ukrainian).

11. Zakharchyshyna, Y. M. (2011). Pedahohichni umovy pidhotovky ofitseriv Zbroinykh Syl Ukrainy do sotsiokulturnoi diialnosti v myrotvorchykh misiiakh [Pedagogical conditions of preparation of officers of the Armed Forces of Ukraine for socio-cultural activity in peacekeeping missions] Zhytomyr, p. 348 (in Ukrainian).

12. Zakharchyshyna, Y. M. (2011). Pidhotovka ofitseriv Zbroinykh Syl Ukrainy do sotsiokulturnoi diialnosti v myrotvorchykh misiiakh [Training of officers of the Armed Forces of Ukraine for socio-cultural activities in peacekeeping missions] Metod. Rekomendatsii, Zhytomyr, Vyd-vo ZhDU im. I. Franka, p. 119 (in Ukrainian).

\section{PЕЗЮМЕ}

Александр Войтех,

Национальный университет оборони Украины имени Ивана Черняховского

\section{Подготовка национального персонала Вооружённых Сил Украины для участия в международных операциях по поддержанию мира и безопасности как педагогическая проблема}

Статья посвящена исследованию состояния разработанности проблематики методического обеспечения подготовки национального персонала Вооруженных Сил Украины к участию в международных операчиях по поддержанию мира и безопасности. Определены профессиональные, психолого-педагогические и социокультурные особенности миротворческой деятельности военнослужащих. На их основе определень специфические принципь организации образовательного процесса подготовки военных специалистов к участию в международных операциях по поддержанию мира $и$ безопасности, а именно: интеграции профессиональной, психолого-педагогической, иноязычно-коммуникативной подготовки; сочетание традиционных и инновационных методов обучения; контекстного обучения; учета социокультурной среды выполнения 
заданий. Обоснованы методические рекомендаџии подготовки национального персонала на основе модели контекстного обучения.

Ключевые слова: методические рекомендации; модель контекстного обучения; специфические принциипы обучения.

\section{SUMMARY}

Oleksandr Voitekh, National Defense University of Ukraine named after Ivan Cherniakhovskyi

\section{Training of national personnel of the Armed Forces of Ukraine for participation in international peace support operations as a Pedagogical Problem}

Introduction. The article is devoted to the study of the state of development of the problems of methodical provision of training of national personnel of the Armed Forces of Ukraine for participation in international peace support operations.

Purpose. Substantiation of methodical recommendations on the use of modern pedagogical approaches and technologies in the process of preparation of national personnel.

Methods. Methods, induction, deduction, classification, systematization and comparative analysis of theoretical sources on the problem of professional training of military specialists.

Results. The professional, psychological and pedagogical and socio-cultural peculiarities of peacekeeping activity of servicemen are determined. On their basis, the specific principles of the organization of the educational process for the training of military specialists for participation in international peace and security operations are identified, namely: integration of professional, psychological and pedagogical, foreign language and communicative training; a combination of traditional and innovative teaching methods; contextual education; taking into account the socio-cultural environment of the tasks. The methodical recommendations of training of national personnel on the basis of the model of contextual education are substantiated.

Originality. The novelty of the results of the study is to apply a contextual approach to the development of a methodology for training national staff. Context learning enables to implement a dynamic model of movement from the educational (using traditional methods, such as lectures, seminars) through quasi-professional (game techniques) and vocational (practice, internship, etc.) to professional peacekeeping activities.

Conclusion. The process of training national staff should be based on specific principles (integration of professional, psycho-pedagogical, foreign-language and communicative preparation, the combination of traditional and innovative teaching methods, contextual learning, taking into account the socio-cultural environment of the tasks), which stem from the regularities of peacekeeping activity.

The methodical basis for training national staff can be a model of contextual education, which is implemented through the systematic use of the conflict context to which the personnel will be involved, the gradual saturation of the educational process with elements of modern international peace and security operations.

The prospects for further research are seen in the substantiation of the pedagogical conditions for the implementation of the methodology of training national personnel based on the model of contextual learning.

Key words: methodological recommendations; model of contextual education; specific principles of training. 